\title{
Oil Yield of Sunflower Cultivated With Different Water Depths and Nitrogen Doses
}

\author{
Jonas de O. Freire ${ }^{1}$, Marcelo T. Gurgel ${ }^{2}$, José F. de Medeiros ${ }^{2}$, Kaline D. Travassos ${ }^{2,3}$, Neyton de O. Miranda ${ }^{2}$ \\ \& Rafael O. Batista ${ }^{2}$ \\ ${ }^{1}$ Federal Institute for Education, Science and Technology of Rio Grande do Norte, Apodi, Brazil \\ ${ }^{2}$ Center for Agrarian Sciences, Federal Rural University of the Semi-arid, Mossoró, Brazil \\ ${ }^{3}$ Coordination for the Improvement of Higher Education Personnel, Brasília, Brazil \\ Correspondence: Neyton de Oliveira Miranda, Centro de Ciências Agrárias, Universidade Federal Rural do \\ Semi-árido, R. Francisco Mota, 572. Pres. Costa e Silva, Mossoró, RN, 59625-900, Brazil. Tel: \\ 55-849-9411-1007. E-mail: neyton@ufersa.edu.br
}

\author{
Received: November 26, $2018 \quad$ Accepted: January 27, $2019 \quad$ Online Published: March 15, 2019 \\ doi:10.5539/jas.v11n4p449 \\ URL: https://doi.org/10.5539/jas.v11n4p449
}

The research is financed in part by the Coordenação de Aperfeiçoamento de Pessoal de Nivel Superior-Brasil (CAPES)_Finance Code 001.

\begin{abstract}
Sunflower is adapted to different soil and climate conditions, but its water and nitrogen requirements are not well defined. This study was carried out in Apodi, Rio Grande do Norte, Brazil, to evaluate the oil yield of sunflower in response to irrigation depth and nitrogen dose. A randomized block experimental design was used with a factorial scheme with four replications. The factors tested were irrigation depths corresponding to $58,80,100$ and $120 \%$ of crop evapotranspiration (water-use efficiency variable), and nitrogen doses corresponding to 40 , 100, 200 and $370 \%$ of the standard dose. Data were submitted to analysis of variance by the F-test, followed by the Tukey test of means and regression analysis. The increase in the water depth until $100 \%$ ETc and in the nitrogen dose until $260 \mathrm{~kg} \mathrm{ha}^{-1}$ promoted increase in the values of all variables, but at higher nitrogen doses the variables decreased. The response surfaces showed stronger response to nitrogen dose for the water depths around $100 \% \mathrm{ETc}$ and for the lower nitrogen doses, and greater water use efficiency for the production of oil for the water depths around $100 \% \mathrm{ETc}$, independently of nitrogen dose.
\end{abstract}

Keywords: Helianthus anuus L., crop response to nitrogen, water use efficiency

\section{Introduction}

Sunflower (Helianthus annuus L.) has desirable agronomic characteristics and potential for expanded cultivation in the Brazilian northeastern semi-arid region. However, to reach the species' potential, it is necessary to employ adequate agricultural practices (Viana et al., 2012).

Sunflower cultivation has global socioeconomic importance (Travassos et al., 2017). World sunflower production in 2014 was 41.34 million metric tons, with Ukraine, Russia and China being the largest producers and Brazil 21st in the ranking (UN Food and Agriculture Organization, 2014).

The production of sunflower is limited by water availability, so the use of irrigation is often necessary. In this respect, sunflower has low water use efficiency, since each liter of water consumed produces less than two grams of dry matter (Campos, Chaves, \& Guerra, 2015).

Water deficit significantly reduces plant production, making it very difficult to grow crops in arid or semi-arid regions, while water excess decreases soil aeration, affects the absorption of nutrients, favors the occurrence of diseases, and allows nutrient leaching. According to Sfredo, Campo, and Sarruge (1984), the most critical phase for water deficit of sunflower is the period between 10 and 15 days before floral initiation and 10 to 15 days after the end of flowering, and the most critical phase regarding water deficit for production of oil occurs in the first ten days after the drying of the ligulate flowers (Castro, Moreira, Oliveira, \& Dechen, 2006). Water use efficiency means water economy because plants that are highly efficient in using water are tolerant to water 
stress and can still produce high yields (Mei, Zhong, Vadez, \& Liu, 2013). In relation to nitrogen, it provides equilibrium between accumulated protein and oil production in oilseed plants, influencing the metabolism for synthesis of reserve compounds in seeds.

Among all the nutrients, nitrogen is found at higher concentrations in plants and is the most limiting for plant growth. It is a constituent of protein and chlorophyll molecules; participates in ion uptake, cell multiplication and differentiation; and acts in the metabolism and nutrition of sunflower crop. The judicious management of nitrogen fertilization for increasing nitrogen use efficiency is very important for maintaining crop production while also reducing environmental pollution by nitrogen losses. This concern is due to the increasing cost of nitrogen fertilizer and to the need to feed a growing world population. The difficulty of managing nitrogen in agriculture is due to its interactions with the environment and its mobility in the soil. Adequate supply of nitrogen to sunflower is essential for optimum yield because it increases root and leaf length, leaf area duration, and photosynthesis. Its deficiency reduces achene yield, while excess lowers the oil content, increases the incidence of pests, diseases and lodging, and may result in excessive vegetative growth in detriment to yield (Ahmad et al., 2018; Moraes, Moreira, Souza, \& Cerezini, 2017; Contreras, Barzan, Contreras, \& Brito, 2017)

According to Klar (1988), adequate soil fertility increases crop water use efficiency, and nitrogen is one of the nutrients with the greatest effect on this efficiency. Thus, the increase in crop yield with fertilization causes an increase in water use efficiency.

The objective of this work was to evaluate the effect of water and nitrogen use efficiency on sunflower oil productivity in the soil and climatic conditions of Apodi, RN, Brazil.

\section{Material and Methods}

The study was developed at the Federal Institute for Education, Science and Technology of Rio Grande do Norte

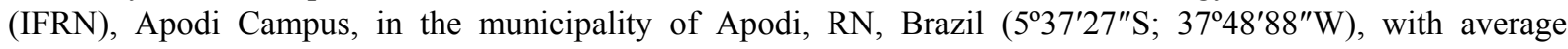
altitude of $131 \mathrm{~m}$.

According to the Köppen classification, Apodi's climate is BSwh', i.e., semiarid and very hot, with the rainy season in the summer extending to the fall. Average annual rainfall is $765 \mathrm{~mm}$, the temperatures range from $22.8{ }^{\circ} \mathrm{C}$ to $34.1{ }^{\circ} \mathrm{C}$, with average of $27.5^{\circ} \mathrm{C}$, and the relative humidity is $66.8 \%$.

The experiment was carried out on a clay-loam Eutrochrept soil, with characteristics in the $0-20$ and $20-40 \mathrm{~cm}$ layers of: pH: 7.2 and 6.4; P: 2.0 and 2.0, K: 305 and 207, Na: 22 and 16, in $\mathrm{mg} \mathrm{dm}^{-3}$; Ca: 7.3 and 3.0, Mg: 2.4 and 1.4, in $\mathrm{cmol}_{\mathrm{c}} \mathrm{dm}^{-3}$; clay: 244 and 313, silt: 298 and 366, sand: 458 and 321, in $\mathrm{g} \mathrm{kg}^{-1}$; soil density: 1.8 and 1.9, particle density: 2.45 and 2.49 , in $\mathrm{kg} \mathrm{dm}^{-3}$; soil field capacity: 0.21 and 0.19 , permanent wilting point: 0.11 and 0.10 , saturation moisture: 0.27 and 0.24 , in $\mathrm{kg} \mathrm{kg}^{-1}$.

The experimental design was a randomized block in a factorial scheme with four replicates. The factors were irrigation depths of $275,381,478$ and $575 \mathrm{~mm}$, corresponding to $58,80,100$ and $120 \%$ of crop evapotranspiration (ETc), and nitrogen doses of 28, 70, 140 and $260 \mathrm{~kg} \mathrm{ha}^{-1}$, corresponding to 40, 100, 200 and $370 \%$ of the recommended dose of $70 \mathrm{~kg} \mathrm{ha}^{-1}$. The experimental area had dimensions of $24 \times 52 \mathrm{~m}$, with 48 rows. The dimensions of the plots were $2 \times 5.5 \mathrm{~m}$, with a useful area of $1 \times 4.5 \mathrm{~m}$ with two plant rows.

Soil tillage consisted of two passes of a disc harrow at an interval of 15 days, followed by the opening of furrows with $0.15 \mathrm{~m}$ depth for basal fertilization. After that, three seeds per hill of the cultivar Catissol 01 were sown at spacing of $0.5 \times 0.35 \mathrm{~m}$. Thinning was performed 11 days after sowing (DAS), leaving one plant per hill, comprising 26 useful plants per plot and a population of 57143 plants ha $^{-1}$.

The irrigation until 17 DAS was performed by a conventional sprinkling system. Three lateral lines with $54 \mathrm{~m}$ length contained ten sprinklers spaced art $6 \times 12 \mathrm{~m}$, with $3.0 \mathrm{~mm}$ nozzles, a range of $11.8 \mathrm{~m}$, and a flow rate of $0.57 \mathrm{~m}^{3} \mathrm{~h}^{-1}$ under a working pressure of $250 \mathrm{kPa}$. After $17 \mathrm{DAS}$, the irrigation depths were differentiated and the system started to operate as a "line source sprinkler system", according to the method proposed by Hanks, Keller, Rasmussen, and Wilson (1976). The system was composed of a central line with ten sprinklers spaced every $6 \mathrm{~m}$. The sprinkler coverage overlap provided greater watering near the lateral line and a decreasing gradient perpendicular to the pipe. The plots were located along the direction perpendicular to the sprinkler line, allowing the differentiation of the irrigation depths. The irrigation system was evaluated and obtained a Christiansen uniformity coefficient (CUC) of $91.5 \%$.

Irrigation was performed every two days, replacing the estimated crop evapotranspiration (ETc) of the period. The equation used to estimate the reference evapotranspiration (ETo) was that of Allen, Pereira, Raes and Smith (2006), with climatic data obtained at the INMET meteorological station (Apodi-A340), located near the experimental area. The crop coefficients $(\mathrm{Kc})$ used to obtain ETc were $0.52 ; 0.70 ; 0.98$ and 0.81 , corresponding 
to sunflower phenological phases I, II, III and IV (Cavalcante Junior et al., 2013), which had duration of 28, 15, 27 and 23 days respectively.

Fertilization consisted of $80 \mathrm{~kg} \mathrm{ha}^{-1}$ of $\mathrm{P}, 34 \mathrm{~kg} \mathrm{ha}^{-1}$ of $\mathrm{K}, 1 \mathrm{~kg} \mathrm{ha}^{-1}$ of $\mathrm{B}$, and $3 \mathrm{~kg} \mathrm{ha}^{-1}$ of $\mathrm{Zn}$, according to the soil analysis and nutritional requirements of the crop cited by Ribeiro, Guimarães, and Alvarez (1999). The application of phosphorus was basal, while potassium, boron and zinc were top dressed at 35 days after sowing

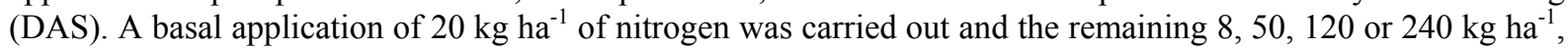
according to the treatments, were top dressed at 35 DAS in the form of ammonium sulfate. No pesticide was applied and weeds were removed by hand at 11 DAS.

Harvesting was performed manually at 93 DAS, when the capitulum presented a light brown color, gradually evolving to dark brown. After the harvest, they were dried in a forced-air oven at $65^{\circ} \mathrm{C}$ for 72 hours.

Measurements included achene yield, oil content, oil yield, water use efficiency (WUE), response to nitrogen dose for production of achenes (RNDA), and water use efficiency for production of oil (WUE $\mathrm{oil}_{\mathrm{il}}$ ). For determination of oil content, grains were ground in a knife mill, weighed (MA) and placed in a Soxhlet extractor, where the material remained in reflux with hexane for six hours. After extraction, the hexane was recovered in a rotary evaporator and then the extracted oil was put in a hot water bath at $65^{\circ} \mathrm{C}$ for 12 hours, for later weighing (MO).

The variables analyzed were calculated by means of the following equations:

$$
\begin{gathered}
\text { Coil }=\frac{\mathrm{MO}}{\mathrm{MA}} \times 100 \\
\text { Yoil }=\text { PROD } \times \frac{\text { Coil }}{100} \\
\text { WUEA }=\frac{\text { PROD }}{\mathrm{L}} \\
\text { RNDA }=\frac{\text { PROD }}{\mathrm{N}} \\
\text { WUEoil }=\frac{\text { Yoil }}{\mathrm{L}}
\end{gathered}
$$

Where,

Coil: content of oil (\%); MO: oil mass (g); MA: mass of sample (g); Yoil: yield of oil ( $\left.\mathrm{kg} \mathrm{ha}^{-1}\right)$; PROD: yield of achenes $\left(\mathrm{kg} \mathrm{ha}^{-1}\right)$; WUEA: water use efficiency in the production achenes $\left(\mathrm{kg} \mathrm{ha}^{-1} \mathrm{~mm}^{-1}\right)$; L: water depth (mm); RNDA: response to nitrogen dose for production of achenes $\left(\mathrm{kg} \mathrm{ha}^{-1} \mathrm{~kg}^{-1} \mathrm{ha}\right)$; $\mathrm{N}$ : dose of nitrogen $\left(\mathrm{kg} \mathrm{ha}^{-1}\right)$; WUEoil: water use efficiency for production of oil $\left(\mathrm{kg} \mathrm{ha}^{-1} \mathrm{~mm}^{-1}\right)$.

The resulting data were submitted to analysis of variance by the F-test $(p<0.05)$. When a significant effect was verified, the means were submitted to the Tukey test, and to regression analysis to obtain the response surfaces, which were drawn in two dimensions.

\section{Results and Discussion}

\subsection{Results}

The factors water depth and nitrogen dose had a significant effect $(\mathrm{p}<0.01)$ on the variables oil content (Coil), oil yield (Yoil), water use efficiency in the production of achenes (WUEA), water use efficiency in oil production (WUEoil), and response to nitrogen dose for the production of achenes (RNDA) of sunflower cultivar Catissol 01. The coefficients of variation obtained for these variables were between 4.1 and $13.4 \%$.

In general, the values of all variables increased until the water depth of $478 \mathrm{~mm}(100 \% \mathrm{ETc})$, and decreased with depths greater than $575 \mathrm{~mm}$ (Table 1). However, the increase in nitrogen dose promoted an increase in the values of Coil, Yoil, WEA and WUEoil until the biggest dose $\left(260 \mathrm{~kg} \mathrm{ha}^{-1}\right)$, whereas RNDA presented inverse results, that is, the increase in nitrogen dose caused large decrease in its use efficiency by the sunflower plants. 
Table 1. Averages of oil content (Coil), oil yield (Yoil), water use efficiency (WUEA), response to nitrogen dose (RNDA) and water use efficiency for oil production (WUEoil) of sunflower cultivar Catissol 01, grown under different water depths and nitrogen doses

\begin{tabular}{|c|c|c|c|c|c|}
\hline \multirow{2}{*}{\multicolumn{2}{|c|}{ Variable analyzed }} & \multicolumn{4}{|c|}{ Water depth (mm) } \\
\hline & & 275 & 381 & 478 & 575 \\
\hline \multicolumn{2}{|l|}{ Coil (\%) } & $31.17 \mathrm{~d}^{*}$ & $33.86 \mathrm{c}$ & $38.29 \mathrm{a}$ & $36.44 \mathrm{~b}$ \\
\hline \multicolumn{2}{|l|}{ Yoil $\left(\mathrm{kg} \mathrm{ha}^{-1}\right)$} & $307.88 \mathrm{~d}$ & $597.16 \mathrm{c}$ & $1082.45 \mathrm{a}$ & $869.16 \mathrm{~b}$ \\
\hline \multicolumn{2}{|l|}{ WUEa $\left(\mathrm{kg} \mathrm{ha}^{-1} \mathrm{~mm}^{-1}\right)$} & $3.58 \mathrm{c}$ & $4.64 \mathrm{~b}$ & $5.92 \mathrm{a}$ & $4.15 \mathrm{~b}$ \\
\hline \multicolumn{2}{|l|}{ RNDA ( $\left.\mathrm{kg} \mathrm{ha}^{-1} \mathrm{~kg}^{-1} \mathrm{ha}\right)$} & $13.26 \mathrm{~d}$ & $23.52 \mathrm{c}$ & $39.79 \mathrm{a}$ & $33.95 \mathrm{~b}$ \\
\hline \multicolumn{2}{|l|}{ WUEoil $\left(\mathrm{kg} \mathrm{ha}^{-1} \mathrm{~mm}^{-1}\right)$} & $1.12 \mathrm{c}$ & $1.57 \mathrm{~b}$ & $2.27 \mathrm{a}$ & $1.51 \mathrm{~b}$ \\
\hline \multirow{2}{*}{\multicolumn{2}{|c|}{ Variable analyzed }} & \multicolumn{4}{|c|}{ Nitrogen dose $\left(\mathrm{kg} \mathrm{ha}^{-1}\right)$} \\
\hline & & 28 & 70 & 140 & 260 \\
\hline \multicolumn{2}{|l|}{ Coil (\%) } & $34.13 b$ & $34.41 \mathrm{~b}$ & $34.98 \mathrm{ab}$ & $36.25 \mathrm{a}$ \\
\hline \multicolumn{2}{|l|}{ Yoil $\left(\mathrm{kg} \mathrm{ha}^{-1}\right)$} & $619.76 \mathrm{c}$ & $680.91 \mathrm{bc}$ & $753.79 \mathrm{ab}$ & $802.20 \mathrm{a}$ \\
\hline \multicolumn{2}{|l|}{ WUEA $\left(\mathrm{kg} \mathrm{ha}^{-1} \mathrm{~mm}^{-1}\right)$} & $4.02 \mathrm{c}$ & $4.40 \mathrm{bc}$ & $4.84 \mathrm{ab}$ & $5.03 \mathrm{a}$ \\
\hline \multicolumn{2}{|l|}{ RNDA ( $\left.\mathrm{kg} \mathrm{ha}^{-1} \mathrm{~kg}^{-1} \mathrm{ha}\right)$} & $63.05 \mathrm{a}$ & $24.10 \mathrm{~b}$ & $15.04 \mathrm{c}$ & $8.33 \mathrm{~d}$ \\
\hline \multicolumn{2}{|l|}{ WUEoil $\left(\mathrm{kg} \mathrm{ha}^{-1} \mathrm{~mm}^{-1}\right)$} & $1.39 \mathrm{~b}$ & $1.53 \mathrm{~b}$ & $1.71 \mathrm{a}$ & $1.84 \mathrm{a}$ \\
\hline \multicolumn{6}{|c|}{ Unfolding of water depths within each nitrogen dose } \\
\hline \multirow{2}{*}{ Variable analyzed } & \multirow{2}{*}{$\begin{array}{l}\text { Dose of N } \\
\left(\mathrm{kg} \mathrm{ha}^{-1}\right)\end{array}$} & \multicolumn{4}{|c|}{ Water depth (mm) } \\
\hline & & 275 & 381 & 478 & 575 \\
\hline \multirow[t]{4}{*}{ Coil (\%) } & 28 & $29.77 \mathrm{cB}$ & $33.76 \mathrm{bA}$ & $37.33 \mathrm{aB}$ & $35.66 \mathrm{abA}$ \\
\hline & 70 & $30.03 \mathrm{cB}$ & $33.78 \mathrm{bA}$ & $37.57 \mathrm{aAB}$ & $36.25 \mathrm{abA}$ \\
\hline & 140 & $31.49 \mathrm{bAB}$ & $33.82 \mathrm{bA}$ & $38.05 \mathrm{aAB}$ & $36.57 \mathrm{aA}$ \\
\hline & 260 & $33.41 \mathrm{cA}$ & $34.10 \mathrm{cA}$ & $40.20 \mathrm{aA}$ & $37.27 \mathrm{bA}$ \\
\hline \multirow[t]{4}{*}{ Yoil $\left(\mathrm{kg} \mathrm{ha}^{-1}\right)$} & 28 & $251.33 \mathrm{dA}$ & $479.02 \mathrm{cB}$ & $957.89 \mathrm{aC}$ & $790.81 \mathrm{bA}$ \\
\hline & 70 & $260.90 \mathrm{dA}$ & $582.03 \mathrm{cAB}$ & $1038.67 \mathrm{aBC}$ & $842.05 \mathrm{bA}$ \\
\hline & 140 & $328.32 \mathrm{dA}$ & $650.11 \mathrm{cA}$ & $1125.24 \mathrm{aAB}$ & $911.48 \mathrm{bA}$ \\
\hline & 260 & $390.97 \mathrm{dA}$ & $677.47 \mathrm{cA}$ & $1208.02 \mathrm{aA}$ & $932.32 \mathrm{bA}$ \\
\hline \multirow[t]{4}{*}{ WUEA $\left(\mathrm{kg} \mathrm{ha}^{-1} \mathrm{~mm}^{-1}\right)$} & 28 & $3.08 \mathrm{bB}$ & $3.76 \mathrm{bB}$ & $5.37 \mathrm{aA}$ & $3.86 \mathrm{bA}$ \\
\hline & 70 & $3.17 \mathrm{cB}$ & $4.52 \mathrm{bAB}$ & $5.84 \mathrm{aA}$ & $4.05 \mathrm{bcA}$ \\
\hline & 140 & $3.79 \mathrm{cAB}$ & $5.06 \mathrm{bA}$ & $6.20 \mathrm{aA}$ & $4.34 \mathrm{bcA}$ \\
\hline & 260 & $4.26 \mathrm{bA}$ & $5.21 \mathrm{bA}$ & $6.29 \mathrm{aA}$ & $4.35 \mathrm{bA}$ \\
\hline
\end{tabular}

Note. ${ }^{*}$ Means followed by the same lowercase letters in the row and by the same uppercase letters in the column do not differ statistically from each other by the Tukey test at 0.05 probability.

The increases in values of the variables when water depth increased from 275 to $478 \mathrm{~mm}$ were $23 \%$ for Coil, $251 \%$ for Yoil, $65 \%$ for WUEA, $200 \%$ for RNDA and $103 \%$ for WUEoil. An even greater increase in water depth to $120 \%$ ETc resulted in decreases of $6 \%$ for Coil, $20 \%$ for Yoil, $30 \%$ for WEA, $16 \%$ for RNDA and 33\% for WUEoil. When the factor nitrogen dose was considered, the increase from 28 to $260 \mathrm{~kg} \mathrm{ha}^{-1}$ caused increases of 6, 29, 25 and 32\% in values of Coil, Yoil, WUEA and WUEoil, respectively, while RNDA decreased by $87 \%$.

The analysis of the interaction between the factors water depth and nitrogen dose (Table 1) showed a significant and rising effect of the increase in nitrogen dose from 28 to $260 \mathrm{~kg} \mathrm{ha}^{-1}$. For Coil, this effect was significant for the water depths from 275 to $478 \mathrm{~mm}$, with increases of 8 and 12\%, respectively. For Yoil, significant effects were observed for water depths of 381 and $478 \mathrm{~mm}$, with increases of 41 and $26 \%$, while for WUEA, significant effects were observed for water depths of 275 and $381 \mathrm{~mm}$, with increases of around $38 \%$. On the other hand, the interaction was significant for all water depths for RNDA and WUEoil, which led to preparation of response surfaces for these variables.

The model with best fit for the response surface of RNDA was the third-order polynomial (Figure 1). In general, the biggest estimated RNDA values (70 to $90 \mathrm{~kg} \mathrm{ha}^{-1} \mathrm{~kg}^{-1}$ ha) were obtained when the water depths were around $100 \%$ ETc ( 450 to $500 \mathrm{~mm}$ ) and nitrogen doses were lower $\left(28\right.$ to $\left.50 \mathrm{~kg} \mathrm{ha}^{-1}\right)$ than the recommended dose. 


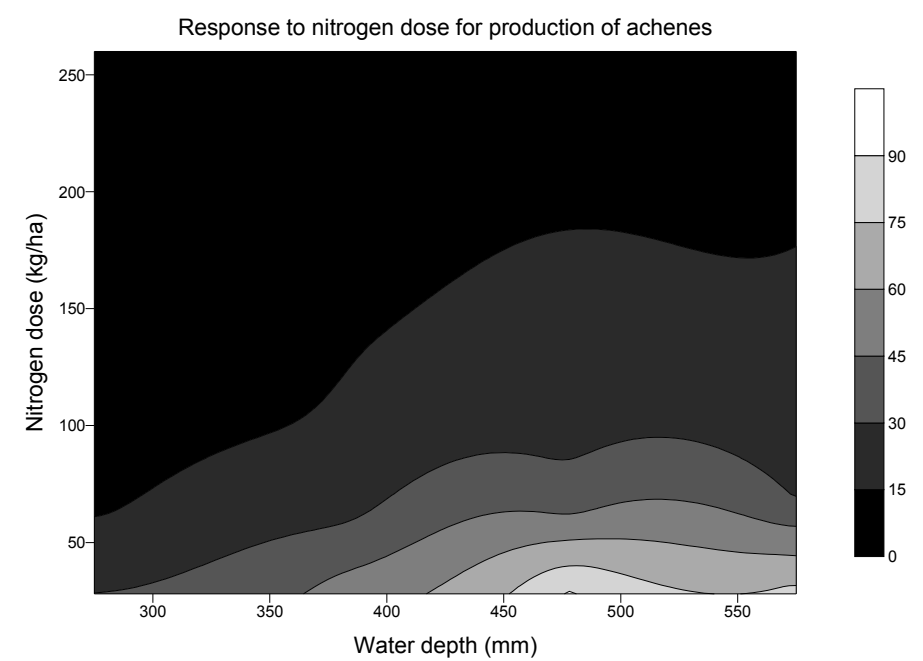

Figure 1. Response surface to nitrogen dose $\left(\mathrm{kg} \mathrm{ha}^{-1} \mathrm{~kg}^{-1}\right.$ ha) for production of achenes as a function of the irrigation depths and nitrogen doses in the sunflower crop

Note. $\mathrm{RNDA}=\mathrm{a}+\mathrm{bD}+\mathrm{cD}^{2}+\mathrm{dD}^{3}+\mathrm{eN}+\mathrm{fN}^{2}+\mathrm{gN}^{3}+\mathrm{hDN}+\mathrm{iDN}^{2}+\mathrm{jD}^{2} \mathrm{~N} \quad \mathrm{r}^{2}=0.96$.

Where, $\mathrm{a}=244.0630^{* *} ; \mathrm{b}=-1.8466^{* *} ; \mathrm{c}=5.81 \times 10^{-3^{* *}} ; \mathrm{d}=-5.08 \times 10^{-6^{* *}} ; \mathrm{e}=-0.6709^{* *} ; \mathrm{f}=0.0115^{* *} ; \mathrm{g}=-2.90$ $\times 10^{-5 * *} ; \mathrm{h}=-4.40 \times 10^{-3 * *} ; \mathrm{i}=5.91 \times 10^{-6^{* *}} ; \mathrm{j}=2.42 \times 10^{-6^{* *}}$.

** significant at $\mathrm{p}<0.01$ by the F-test.

When the WUEoil was considered, the model with best fit for the response surface was also the third-order polynomial (Figure 2). In general, the biggest estimated WUEoil values (2.15 to $2.55 \mathrm{~kg} \mathrm{ha}^{-1} \mathrm{~mm}^{-1}$ ) were obtained with water depth around $100 \% \mathrm{ETc}$, regardless of nitrogen dose.

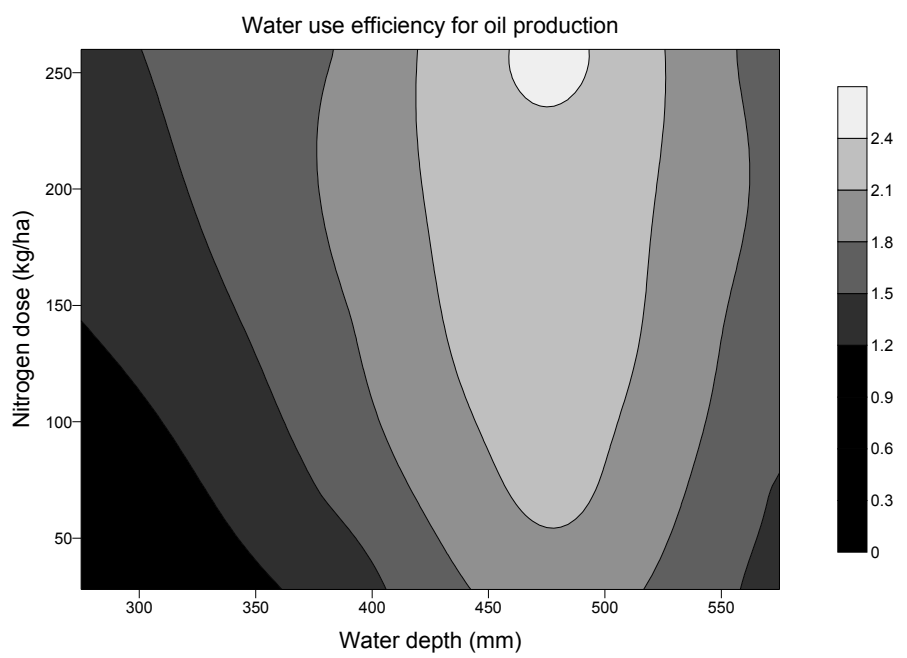

Figure 2. Response surface of water use efficiency for oil production $\left(\mathrm{kg} \mathrm{ha}^{-1} \mathrm{~mm}^{-1}\right)$ as a function of irrigation depths and nitrogen doses in the sunflower crop

Note. WUEoil $=\mathrm{a}+\mathrm{bL}+\mathrm{cL}^{2}+\mathrm{dL}^{3}+\mathrm{eN}+\mathrm{fN}^{2} \quad \mathrm{r}^{2}=0.8813$.

Where, $\mathrm{a}=16.5886^{* *} ; \mathrm{b}=-0.1343^{* * *} ; \mathrm{c}=3.64 \times 10^{-4^{* * *}} ; \mathrm{d}=-3.08 \times 10^{-7^{* * *}} ; \mathrm{e}=4.20 \times 10^{-3^{* *}} ; \mathrm{f}=-7.86 \times 10^{-6^{*}}$

** significant at $\mathrm{p}<0.01$ by the $\mathrm{F}$ test, $* *$ significant at $\mathrm{p}<0.05$.

\subsection{Discussion}

The decrease in oil content with irrigation depths larger or smaller than the standard depth $(478 \mathrm{~mm})$ can be attributed to water stress, which causes the closure of the stomata, reducing transpiration, photosynthesis and respiration, or to the excess of water in the soil, which lowers the concentration of $\mathrm{O}_{2}$ and causes reduction in 
chlorophyll and increase in carotenoids of plants. This reduces photosynthetic rates and the accumulation of photosynthates, thus reducing the sunflower oil content.

In agreement with our results, Silva, Bezerra, Sousa, Pereira Filho, and Freitas (2011) also observed an increase in the oil content of the cultivar Catissol 01 with the increase in water depth. They obtained the highest oil content (43\%) with the water depth of $533.7 \mathrm{~mm}$, results larger than those obtained in our experiment. Higher oil contents were also observed by Ali, Ashraf, and Anwar, (2009) when comparing normally irrigated hybrids with sunflower plants submitted to water stress in the vegetative and reproductive phases. On the other hand, Gomes et al. (2012) did not observe differences in oil content as a function of irrigation depths. Probably their study used different cultivars under different management conditions.

Although small, the increase in oil content $(6 \%)$ when nitrogen dose was increased from 28 to $260 \mathrm{~kg} \mathrm{ha}^{-1}$ differed from results obtained by Carvalho and Pissaia (2002), who found no change in oil content when the nitrogen dose varied from zero to $125 \mathrm{~kg} \mathrm{ha}^{-1}$, and also from those obtained by Zheljazkov et al. (2009), who observed a reduction in oil content in four hybrids with increasing doses of nitrogen $\left(0,67,134\right.$ and $\left.202 \mathrm{~kg} \mathrm{ha}^{-1}\right)$. Overall, nitrogen acts on the equilibrium between the contents of proteins and oil, as it influences the metabolism for synthesis of reserve compounds in seeds.

We observed increased oil yield when water depth increased until 100\% ETc $(478 \mathrm{~mm})$ and decrease in Yoil with a greater increase in water depth. An increase in Yoil for the cultivar Catissol 01 was also observed by Silva et al. (2011) when they increased the water depths applied. However, they obtained a bigger Yoil (1851.55 kg $\left.\mathrm{ha}^{-1}\right)$ than ours using a greater water depth $(150 \%$ Etc).

Increased oil production with increasing water depths was also observed by Silva, Faria, Morais, Andrade and Lima (2007), who obtained lower Yoil than that obtained by us. These authors obtained Yoil values of 633.47 and $467.42 \mathrm{~kg} \mathrm{ha}^{-1}$ for cultivars H250 and H251 when they applied a water depth of $522.14 \mathrm{~mm}(130 \% \mathrm{ETc})$.

The increase in nitrogen doses from 28 to $260 \mathrm{~kg} \mathrm{ha}^{-1}$ in our study caused an increase of $29 \%$ in oil yield. An increase in Yoil with increased nitrogen dose was also reported by Zagonel and Mundstock (1991) and Lobo, Grassi Filho, and Coelho (2012). The highest values obtained by these authors were respectively 1041 and 954 $\mathrm{kg} \mathrm{ha}^{-1}$ for the cultivars DK180 and Contissol 711, bigger than those obtained in our experiment. Although the Yoil of sunflower is due both to the production of achenes and to their oil content, the small variations in Coil when compared to the large variations in Yoil indicated that the production of achenes was more important for the increase in Yoil.

Our observation of increased WUEA as a function of the water depths only until $100 \%$ ETc followed by a decrease with greater water depths (120\% Etc) is in line with Gomes et al. (2012), who also obtained the best irrigation efficiency with $100 \%$ ETc, although their result $\left(7.43 \mathrm{~kg} \mathrm{ha}^{-1} \mathrm{~mm}^{-1}\right)$ was larger than ours. Meanwhile, the reduction in WUEA for the cultivar Catissol 01, observed by Duarte et al. (2012), when applying the highest irrigation depth in a study about water suspension, diverged from our results.

The notable reduction in WUEA for the water depths lower than $100 \%$ ETc is related to the decrease in the yield of achenes due to water deficit at the lower water depths. Meanwhile, the decrease in WUEA with increase of the water depth to $120 \%$ ETc can be attributed to the reduction in photosynthetic rate due to the decrease in soil aeration, which reduced the yield of achenes.

The increase in WUEA with rising doses of nitrogen from 28 to $260 \mathrm{~kg} \mathrm{ha}^{-1}$ is attributed to the increase in the yield of achenes promoted by the larger nitrogen doses. These results show the importance of defining adequate water depth and nitrogen dose to maximize the production per unit of applied water, thus reducing production costs.

Overall, the effect of the factor water depth was more pronounced than the effect of the nitrogen doses for the increase in values of Coil, Yoil and WUEA. The increase in water depth resulted in larger increases in the values of these variables compared to the increases due to increasing nitrogen doses (Table 1).

The RNDA as a function of the water depths was bigger for the water depths around $100 \mathrm{ETc}$ and coincided with the lower nitrogen doses (Figure 1). The increase in nitrogen dose caused a decrease in the RNDA independently of water depth applied. The positive individual effect of the water depth was substantial, as was the negative individual effect of the factor nitrogen dose (Table 1). Due to the exploitation by the sunflower of the nitrogen contained in the soil organic matter, nitrogen doses above the crop needs improved vegetative growth to the detriment of the yield of achenes. Thus, the agronomically viable region of the response surface encompasses the water depths of 440 and $540 \mathrm{~mm}$ and the nitrogen doses of 28 and $50 \mathrm{~kg} \mathrm{ha}^{-1}$.

In general, the negative effect of nitrogen doses on RNDA of the sunflower plants was more pronounced than the 
effect of water depths, evidenced by the fact that the positive effect of the water depth is depicted in a small portion of the response surface (Figure 1). The tendency for decrease in RNDA follows the direction of the higher nitrogen doses, while a small area of greater RNDA is localized around the water depth of $100 \%$ ETc.

The response surface shows that biggest WUEoil values occurred with water depths around $100 \%$ ETc (450 to $500 \mathrm{~mm}$ ), regardless of nitrogen dose, and decreased with the lower and higher water depths. Figure 2 shows that values of WUEoil decreased progressively toward the lower water depths but did not vary with nitrogen dose. Considering that the production of oil depends on the production of achenes, whose largest production occurred with water depths around $100 \% \mathrm{ETc}$, this is the best water depth for the production of oil.

The WUEoil value was more sensitive to the water depths than to the nitrogen doses, as demonstrated by the greater individual effects of water depth on Coil (23\%) and Yoil $(251 \%)$ than the individual effect of nitrogen dose, which was 6 and 29\% for Coil and Yoil, respectively (Table 1).

Our results corroborate those obtained by Gomes et al. (2012). They obtained the best WUEoil $\left(3.12 \mathrm{~kg} \mathrm{ha}^{-1}\right.$ $\mathrm{mm}^{-1}$ ) with the water depth equivalent to $100 \%$ ETc. This efficiency decreased when they used water depths equivalent to 200,150 and $50 \%$ of ETc. A reduction in WUEoil with the increase in irrigation depths was observed by Duarte et al. (2012), which diverges from our work.

The reduction of 50\% in WUEoil when the smallest water depth $(275 \mathrm{~mm})$ was applied, in comparison with the water depth equivalent to $100 \%$ of the ETc $(478 \mathrm{~mm})$, is due to a drastic reduction of the yield of achenes, which is due to the water deficit when the water depth was reduced. The reduction in WUEoil with the increase of the water depth to $575 \mathrm{~mm}(120 \%$ of ETc) may be related to the reduced production of photoassimilates when soil aeration decreased and to the decline in the yield of achenes.

\section{Conclusion}

The increase in the water depth until $100 \%$ ETc and in the nitrogen dose until $260 \mathrm{~kg} \mathrm{ha}^{-1}$ promoted increase in the values of all variables except the response to nitrogen dose.

Overall, the effect of water depth was more important than the effect of nitrogen dose.

The biggest response to nitrogen dose was observed for the water depths around $100 \%$ ETc and for the lower nitrogen doses.

The biggest water use efficiency for the production of oil was observed for the water depths around $100 \%$ ETc, irrespective of nitrogen dose.

\section{References}

Ahmad, M. I., Ali, A., He, L., Latif, A., Abbas, A., Ahmad, J., ... Mahmood, M. T. (2018). Nitrogen effects on sunflower growth: a review. International Journal of Biosciences, 12(6), 91-101.

Ali, Q., Ashraf, M., \& Anwar, F. (2009). Physico-chemical attributes of seed oil from drought stressed sunflower (Helianthus annuus L.) plants. Grasas y Aceites, 60(5), 475-481.

Allen, R. G., Pereira, L. S., Raes, D., \& Smith, M. (2006) Evapotranspiration del cultivo: Guias para la determinación de los requerimentos de agua de los cultivos (Estudio FAO Riego Drenaje 56, p. 298). Rome, FAO.

Campos, V. B., Chaves, L. H. G., \& Guerra, H. O. C (2015). Adubação com NPK e irrigação em Luvissolo: Comportamento vegetativo. Revista Ambiente e Água, 10(10), 221-233.

Carvalho, D. B., \& Pissaia, A. (2002). Cobertura nitrogenada em girassol sob plantio direto na palha: I-Rendimento de grãos e seus componentes, índice de colheita e teor de óleo. Scientia Agraria, 3(1-2), 41-45. https://doi.org/10.5380/rsa.v3i1.1029

Castro, C., Moreira, A., Oliveira, R. F., \& Dechen, A. R. (2006). Boro e estresse hídrico na produção do girassol. Ciência e Agrotecnologia, 30(2), 214-220. https://doi.org/10.1590/S1413-70542006000200004

Cavalcante Junior, E. G., Medeiros, J. F., Melo, T. K., Espinola Sobrinho, J., Bristot, G., \& Almeida, B. M. (2013). Necessidade hídrica da cultura do girassol irrigado na chapada do Apodi. Revista Brasileira de Engenharia Agrícola e Ambiental, 17(3), 261-267. https://doi.org/10.1590/S1415-43662013000300003

Contreras, H. A. S., Barzan, R. R., Contreras, M. S., \& Brito, O. R. (2017). Growth, yield and agronomic efficiency of rice (Oryza sativa L.) cv. IAPAR 117 affected by nitrogen rates and sources. Acta Agronomica, 66(4), 558-565. https://doi.org/10.15446/acag.v66n4.59101 
Duarte, J. M. L., Lima, A. D., Nascimento, R. S., Viana, T. V. A., Saraiva, K. R., \& Azevedo, B. M. (2012). Eficiência no uso da água na produção de óleo do girassol (Helliantus annuus L.), sob suspensão hídrica. Revista Brasileira de Agricultura Irrigada, 6(3), 166-175. https://doi.org/10.7127/RBAI.V6N300081

FAO (Food and Agriculture Organization of the United Nations). (2014). FAOSTAT-Statistics database 2014. Retrieved from http://faostat.fao.org

Gomes, E. P., Fedri, G., Ávila, M. R., \& Biscarro, G. A., Resende, R. K. S., \& Jordan, R. A. (2012). Produtividade de grãos, óleo e massa seca de girassol sob diferentes lâminas de irrigação suplementar. Revista Brasileira de Engenharia Agricola e Ambiental, 16(3), 237-246. https://doi.org/10.1590/S1415 $-43662012000300001$

Hanks, R. J., Keller, J., Rasmussen, V. P., \& Wilson, G. D. (1976). Line source sprinkler for continuous variable irrigation-crop production studies. Soil Science Society of America Journal, 40(3), 426-429. https://doi.org/ 10.2136/sssaj1976.03615995004000030033x

Klar, A. E. (1998). A água no sistema solo-planta-atmosfera (2nd ed., p. 408). São Paulo, Nobel.

Lobo, T. F., Grassi Filho, H., \& Coelho, H. A. (2012). Efeito da adubação nitrogenada na produção do girassol. Cientifica, 40(1), 59-68.

Mei, X. R., Zhong, X. L., Vadez, V., \& Liu, X. Y. (2013). Improving water use efficiency of wheat crop varieties in the North China Plain: Review and Analysis. Journal of Integrative Agriculture, 12(7), 101-108. https://doi.org/10.1016/S2095-3119(13)60437-2

Moraes, L. A. C., Moreira, A., Souza, L. G. M., \& Cerezini, P. (2017). Nitrogen Sources and Rates Effect on Yield, Nutritional Status, and Yield Components of Sunflower. Communications in Soil Science and Plant Analysis, 48(14), 1627-1635. https://doi.org/10.1080/00103624.2017.1373792

Ribeiro, A. C., Guimarães, P. T. G., \& Alvarez, V. H. (1999). Recomendação para o uso de corretivos e fertilizantes em Minas Gerais (p. 359). Aproximação. Viçosa, Comissão de Fertilidade do Solo do Estado de Minas Geraisp.

Sfredo, G. J., Campo, R. J., \& Sarruge, J. R. (1984). Girassol: nutrição mineral e adubação (p. 36). Londrina, Embrapa CNPSO.

Silva, A. R. A., Bezerra, F. M. L. A., Sousa, C. C. M., Pereira Filho, J. V., \& Freitas, C. A. S. (2011). Desempenho de cultivares de girassol sob diferentes lâminas de irrigação no Vale do Curu, CE. Revista Ciência Agronômica, 42(1), 57-64. https://doi.org/10.1590/S1806-66902011000100008

Silva, M. L. O., Faria, M. A., Morais, A. R., Andrade, G. P., \& Lima, E. M. C. (2007). Crescimento e produtividade do girassol cultivado na entressafra com diferentes lâminas de água. Revista Brasileira de Engenharia Agrícola e Ambiental, 11(5), 482-488. https://doi.org/10.1590/S1415-43662007000500006

Travassos, K. D., Barros, H. M. M., Soares, F. A. L., Gheyi H. R., Tavares, M. G., \& Uyeda, C. A. (2017). Crescimento de cultivares de girassol submetido à irrigação com águas de diferentes salinidades. Revista Espacios, 38(46), 6.

Viana, T. V. A., Lima, A. D., Marinho, A. B., Duarte, J. M. L., Azevedo, B. M., \& Costa, S. C. (2012). Lâminas de irrigação e coberturas do solo na cultura do Girassol, sob condições Semiáridas. Irriga, 17(2), 126-136. https://doi.org/10.15809/irriga.2012v17n2p126

Zagonel, J., \& Mundstock, C. M. (1991). Doses e épocas de aplicação de nitrogênio em cobertura em duas cultivares de girassol. Pesquisa Agropecuária Brasileira, 26(9), 1487-1492.

Zheljazkov, V. D., Vick, B. A., Baldwin, B. S., Buehring, N., Astatkie, T., \& Johnson, B. (2009). Oil Content and Saturated Fatty Acids in Sunflower as a Function of Planting Date, Nitrogen Rate, and Hybrid. Agronomy Journal, 101(4), 1003-1011. https://doi.org/10.2134/agronj2009.0011

\section{Copyrights}

Copyright for this article is retained by the author(s), with first publication rights granted to the journal.

This is an open-access article distributed under the terms and conditions of the Creative Commons Attribution license (http://creativecommons.org/licenses/by/4.0/). 